Notices of Memoirs-Drawings in Spanish Caves. 173

other Jurassic fossils figured as Cirripedes are very doubtful, and an examination of the originals will probably show that they do not belong to the Cirripedia, but from the descriptions and figures it is impossible to say what they really are.

\title{
NOTIOFS OF MFMOIRS.
}

Drawings in Spanish Caves.

Los Grabados de la Cueva de Prnches. By Eddardo HernandezPacheco. Comisión de Investigaciones Paleontológicas y Prehistóricas, Mem. No. 17, Madrid, 1917.

7 HE Spanish Government is to be congratulated on the valuable memoirs on Geology, Prehistoric Archæologr, Zoology, and Botany which are being issued in rapid succession from the National

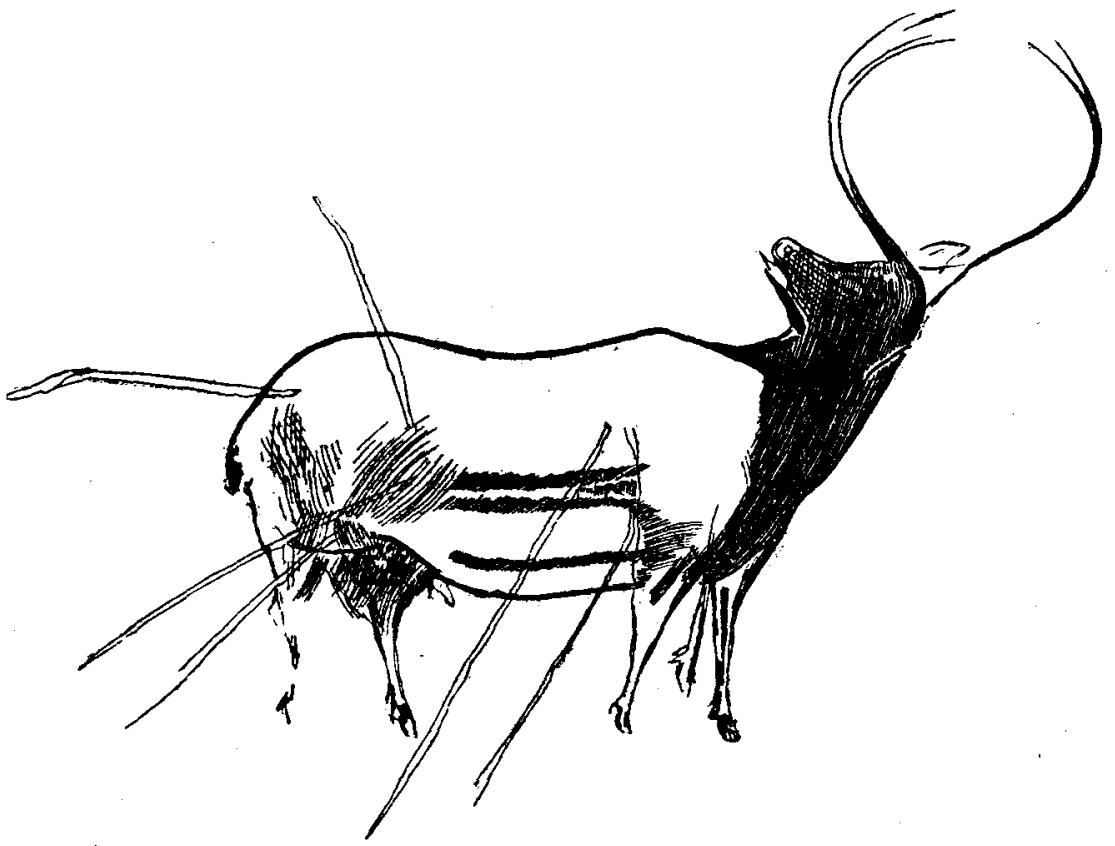

Drawing of a hunted deer, pierced with arrows, on the wall of the carern of La Peña, San Román de Candamo, Asturias, Spain. Original about 4 feet in depth.

Museum of Natural Sciences in Madrid. They are making known the scientific treasures of Spain in a manner which bas not hitherto been possible; while their attractive style and their profusion of admirable illustrations render them all the more welcome. The memoirs on the prehistoric drawings in the Spanish caves are especially interesting, and the latest, by Dr. Hernández-Pacheco, maintains the standard we have now been led to expect. 
The new memoir deals with incised drawings, chiefly of deer, in a remote cave in the province of Burgos. Like many of the other caves ornamented by Magdalenian man, it consists of little more than irregular crevices in the Cretaceous limestone and could scarcely have been used as a habitation. Dr. Pacheco thinks that the drawings were made there by the hunters merely under the impression that they would have some mystic influence on their success in the chase. Some of the deer seem to be represented as pierced by arrows, and Dr. Pacheco publishes for comparison with them a most remarkable incised drawing of a hunted deer lately found in the cave of Ia Peña, in San llomán de Candamo, in Asturias. This drawing is so extraordinary that we venture to reproduce it here. It shows the deer pierced by several arrows, standing at bay, in erident distress, with protruded tongue. Of all the drawings of game hitherto found in the Spanish and French cares this is probably the most animated. The effect is even enhanced by the skilful use of lines of shading, and we cannot but admire the artistic powers of the old hunters who were able to produce such work on irregular surfaces in dark recesses underground.

A. S. W.

\section{REVIFWS. \\ Memotrs of the Geological Survey.}

I.-The Geologr of the South Wales Conlfield. Part IV : The Codntry arodnd Pontyphidd and Maestêg. By A. Strahan, F.R.S., R. H. 'Tiddeman, and W. Grason. Second edition, revised by W. Gibson and T. G. Cantrill. Memoirs of the Geological Survey, 1917. pp. ix +160 . Price 3s. 6d.

1 IHIS memoir deals chiefly with the occurrence of the coal-seams 1 in this area and their correlation, both at their outcrops and in the shafts of the mines, the character of the coals being described in a separate memoir dealing with the whole of the coalfield. The coal occurs mainly in the Lower Coal Series, but also to some extent in the Pennant Series; the Upper Coal Series is only present in one or two places in the area. The higher coals are more bituminous than the lower, and all the coals lose bituminous matter in a westerly and north-westerly direction, as is common in South Wales. Since the issue of the first edition numerous changes in the mines and mining have taken place ; for example, steam coals are now no longer worked west of the Ogwr, while these coals are now being won from deep shafts sunk through the Pennant Series north and north-west of Llantrisant. Also the mining in the Ogwr and Avan valleys has been considerably developed as a consequence of the building of docks at Port Talbot, while the mining conditions of the Rhondda valleys have altered but little. The memoir contains chapters on the geological structure, the Mesozoic rocks, and the glacial deposits. It is illustrated by figures and vertical sections showing the correlation of the coal-seams, and is accompanied by a colourprinted map (Sheet 248) on the scale of one mile to the inch, which is a very good example of colour-printing. $\quad$ W. H. W. 